\title{
Penilaian Pengetahuan Siswa Dengan Jaringan Syaraf Tiruan Algoritma Perceptron
}

\author{
Syarifuddin N. Kapita1, Samlan Mahdi' ${ }^{2}$, Firman Tempola ${ }^{3}$
}

1,2,3Program Studi Teknik Informatika, Fakultas Teknik, Universitas Khairun email: ${ }^{1 S y a r i f u d d i n . K a p i t a . @ u n k h a i r . a c . i d ; ~}{ }^{2}$ Samlanmahdi02@gmail.com; ${ }^{3}$ irman.tempola@unkhair.ac.id

$\begin{array}{ll}\text { Received } & : 14-03-2020 \\ \text { Accepted } & : 18-04-2020 \\ \text { Available online } & : 31-05-2020\end{array}$

\begin{abstract}
ABSTRAK
Dalam proses penilaian pengetahuan siswa pada Sekolah Dasar Negeri 1 Kota Ternate masih menggunakan software MS excel dan membutuhkan waktu kurang lebih 2 sampai 4 hari, sehingga dianggap kurang efektif. Penelitian ini bertujuan untuk menerapkan Jaringan Syaraf Tiruan Perceptron agar memudahkan pekerjaan penilaian Guru di SD Negeri 1 Kota Ternate. Jaringan syaraf tiruan merupakan salah satu sistem pemrosesan informasi yang didesain dengan meniru cara kerja otak manusia dalam menyelesaikan suatu masalah secara cepat dan tepat. Dalam pengolahan penilaian dengan algoritma perceptron, dibutuhkan data pelatihan (training) dan pengujian (testing) untuk mengklasifikasikan data hasil belajar siswa. Metode pengembangan sistem yang digunakan yaitu prototype. Pengujian sistem dilakukan dengan metode white box. Data yang digunakan adalah data klasifikasi hasil belajar siswa pada ranah pengetahuan yakni Hasil Penilaian Harian (HPH), Hasil Penilaian Tengah Semester (HPTS), dan Hasil penilaian Akhir Semester (HAS). Hasil penelitian menunjukkan bahwa tingkat keakuratan tertinggi terjadi di perlakuan awal dengan akurasi yang diperoleh sebesar $96 \%$, sehingga dapat disimpulkan bahwa sistem Jaringan Syaraf Tiruan dengan algoritma Perceptron dapat diimplementasikan untuk penilaian siswa pada kurikulum 2013.
\end{abstract}

Kata Kunci: Jaringan syaraf tiruan, algoritma perceptron, klasifikasi, akurasi, kurikulum

\begin{abstract}
In the process of student assessment in SD Negeri 1 Kota Ternate, they still use MS Excel software and it takes approximately 2 to 4 days, so it is assumed to be less effective. This study aims to apply the Perceptron Artificial Neural Network to facilitate the work of teacher assessment in SD Negeri 1 Kota Ternate. Artificial neural network is an information processing system that is designed to mimic the workings of the human brain in solving problems quickly and accurately. In processing the assessment using the perceptron algorithm, training data and testing are needed to classify student learning outcomes data. The system development method used is prototype. System testing is done by the white box method's. The data used are data classification of student learning outcomes in the realm of knowledge, namely Daily Assessment Results (HPH), Mid Semester Assessment Results (HPTS), and Final Semester Assessment Results (HAS). The results showed that the highest level of accuracy occurred in the initial treatment with an accuracy of $96 \%$, so it can be concluded that the Artificial Neural Network system with the Perceptron algorithm can be implemented for student assessment in the 2013 curriculum.
\end{abstract}

Keywords: Artificial neural networks, perceptron algorithm, classification, accuracy, curriculum 


\section{TECHNO: Vol. 09 (01) Mei 2020}

\section{PENDAHULUAN}

Keberhasilan pembangunan pendidikan yang berkualitas dipengaruhi oleh ketersediaan berbagai komponen pendukungnya. Salah satu diantaranya adalah kurikulum yang dikembangkan dan digunakan pada tataran satuan pendidikan (Purnomo, 2017). Tidak bisa dipungkiri bahwa perubahan kurikulum selalu mengarah pada perbaikan sistem pendidikan. Perubahan tersebut dilakukan karena dianggap belum sesuai dengan harapan yang diinginkan, sehingga perlu adanya revitalisasi kurikulum (Sari et al., 2015).

Dalam menentukan penilaian siswa pada kurikulum 2013, melibatkan beberapa kriteria yang harus diambil karena ada tiga ranah kompetensi yang dinilai, yaitu kompetensi sikap, kompetensi pengetahuan, dan kompetensi keterampilan. Di dalam kompetensi sikap memiliki 4 jenis penilaian yaitu penilaian diri, penilaian antar teman, observasi, dan jurnal. Sementara dalam kompetensi keterampilan terdapat 3 jenis penilaian yaitu penilaian praktek, portofolio, dan proyek. Pada kompetensi pengetahuan memiliki beberapa kompetensi inti yang harus dinilai (Kemendikbud, 2016). Dalam menentukan penilaian akhir siswa dengan kategori sangat baik, baik, dan cukup maka umumnya para Guru melakukan perhitungan aspek pengetahuan siswa dengan cara menjumlahkan setiap hasil belajar meliputi; Hasil Penilaian Harian (HPH), Hasil Penilaian Tengah Semester (HPTS), dan Hasil penilaian Akhir Semester (HAS) lalu dibagi dengan ketiga variabel tersebut (Ardian \& Abidin, 2014).

Pada proses penilaian yang dilaksanakan di sekolah, umumnya penilaian pada ranah pengetahuan dilakukan dengan menggunakan software M.S excel. Setelah mendapatkan nilai akhir pengetahuan, lalu Guru menginputnya ke dalam aplikasi rapor yang masih dalam bentuk excel untuk mengetahui predikat siswa dengan kategori sangat baik, baik, dan cukup. Dalam proses penilaian ini, dibutuhkan waktu selama kurang lebih 2 sampai 4 hari. Oleh karena itu, perlu adanya sistem untuk memproses informasi secara cepat dan tepat.

Jaringan Syaraf Tiruan merupakan salah satu sistem pemrosesan informasi yang didesain dengan meniru cara kerja otak manusia dalam menyelesaikan suatu masalah dengan melakukan proses belajar melalui perubahan bobot sinapsisnya berbasis pada data time-series (history) (Matondang, 2013). Menurut Kokyay et al., (2020), jaringan syaraf tiruan juga mampu menemukan hubungan yang tidak diketahui dan tidak dapat diprediksi antara data dengan suatu aplikasi yang memprediksi output. Selain itu, jaringan syaraf tiruan juga dapat dengan jelas mengungkapkan hubungan yang tidak dapat dikenali karena modelnya bukan linier. Jaringan syaraf tiruan adalah mekanisme komputasi yang mampu memperoleh, mewakili, menghitung pemetaan dari suatu multivariat ke informasi yang lain, dan memberikan suatu himpunan data yang mewakili pemetaan tersebut (Kapita, 2020). Jaringan syaraf tiruan dapat digambarkan sebagai sebuah simulasi dari koleksi model saraf biologi. Model saraf ditunjukkan dengan kemampuannya dalam melakukan emulasi, analisa, prediksi, dan asosiasi data (Kosasi, 2014). Jaringan syaraf tiruan Perceptron merupakan salah satu metode pembelajaran yang terbimbing (Supervise Learning Method). Metode terbimbing merupakan metode pelatihan yang memasukkan target keluaran dalam data untuk proses pelatihan. Hasil dari pelatihan tersebut akan menghasilkan bobot baru yang digunakan untuk proses pengenalan (Paramita, 2016).

Algoritma Perceptron adalah suatu bentuk jaringan syaraf sederhana dan merupakan salah satu cabang ilmu bidang kecerdasan buatan (Artificial Intelegence). Metode ini digunakan sebagai pengklasifikasian suatu tipe pola tertentu yang lebih dikenal dengan pemisahan secara linier. Perceptron pada jaringan syaraf tiruan dengan satu lapisan memiliki bobot yang bisa diatur. Algoritma-algoritma yang digunakan dalam aturan Perceptron ini akan mengatur parameter-parameter bebasnya melalui proses pembelajaran. Pada metode Perceptron, proses 
pembelajaran untuk mendapatkan bobot akhir dilakukan secara berulang kali sampai sudah tidak terjadi lagi kesalahan (error). Kesalahan yang terjadi berupa output jaringan memiliki nilai yang sama dengan target yang diharapkan (Arliyanto, 2016).

Algoritma Perceptron pernah digunakan oleh (Arliyanto, 2016) untuk pengembangan tes minat dan bakat potensi siswa di bidang olahraga sepak bola. Selain itu, penentuan penilaian siswa juga pernah digunakan oleh Wijaya, (2019) dengan menggunakan algoritma Simple Additive weighting. Selain itu, Lesnussa et al., (2015) juga menggunakan jaringan syaraf tiruan Backpropagation untuk memprediksi prestasi siswa SMA. Di tingkat perguruan tinggi, penerapan Jaringan Syaraf Tiruan Perceptron pernah dilakukan oleh Heryati et al., (2018) untuk memprediksi prestasi mahasiwa. Pada penelitian ini, peneliti menerapkan algoritma Perceptron pada jenjang yang berbeda, yakni dilakukan di SD Negeri 1 Kota Ternate dalam melakukan proses penilaian pengetahuan siswa yang telah menerapkan kurikulum 2013.

\section{METODE PENELITIAN}

Tahap Pertama, melakukan pengembangan sistem dengan prototype dengan langkah-langkah sebagai berikut (Barakbah et al., 2013):

1. Mendengarkan Pelanggan

Pada tahap ini dilakukan pengumpulan kebutuhan dari sistem dengan cara mendengar keluhan dari pelanggan (pengguna), yaitu tentang proses penilaian siswa pada ranah pengetahuan yang mengalami keterlambatan (dari segi waktu) dalam penilaian. Sehingga dibutuhkan sebuah sistem dengan metode perhitungan yang memiliki tingkat akurasi tinggi untuk mengolah data hasil belajar siswa dan membantu pihak sekolah agar menentukan keputusan secara cepat dan tepat.

2. Merancang dan Membuat Prototype

Dalam tahap ini dilakukan perancangan dan pengkodean untuk sistem yang diusulkan yang mana tahapannya meliputi perancangan proses-proses yang akan terjadi didalam sistem, perancangan use case, perancangan struktur tabel, perancangan Entity Relationship Diagram (ERD), dan perancangan antar muka (interfaces) keluaran, serta dilakukan tahap pengkodean terhadap rancanganrancangan yang telah didefinisikan (Prabowo, 2014). Kelengkapan software dan hardware yang dibuat, disesuaikan dengan kebutuhan sistem dari keluhan pelanggan (pengguna) yaitu aplikasi klasifikasi penilaian siswa.

3. Uji Coba

Pada tahap ini, aplikasi klasifikasi penilaian siswa dilakukan pengujian dengan mengunakan white box dan bagian yang akan di uji adalah semua keputusan logis dari sisi true dan false dari algoritma Perceptron oleh pelanggan atau pengguna. Kemudian dilakukan evaluasi kekurangan-kekurangan dari kebutuhan pelanggan. Jika pengguna merasa aplikasi klasifikasi penilaian siswa yang dibuat masih belum sesuai dengan yang diinginkan, aplikasi akan diperbaiki dengan kembali pada tahap pertama.

Tahap Kedua, pengumpulan data yang diawali dengan melakukan wawancara. Kemudian dilakukan pengambilan data sebanyak 73 siswa, dengan data hasil belajar siswa yang telah terekam dalam satu semester berupa Hasil Penilaian Harian (HPH), Hasil Penilaian Tengah Semester (HPTS), dan Hasil Penilaian Akhir Semester (HPAS). 
Tahap Ketiga, pemecahan masalah. Untuk melaksanakan pemecahan masalah, maka peneliti membuat suatu diagram alir berupa tahapan-tahapan yang dilakukan pada metode Perceptron, sebagaimana terlihat pada Gambar 1 berikut.

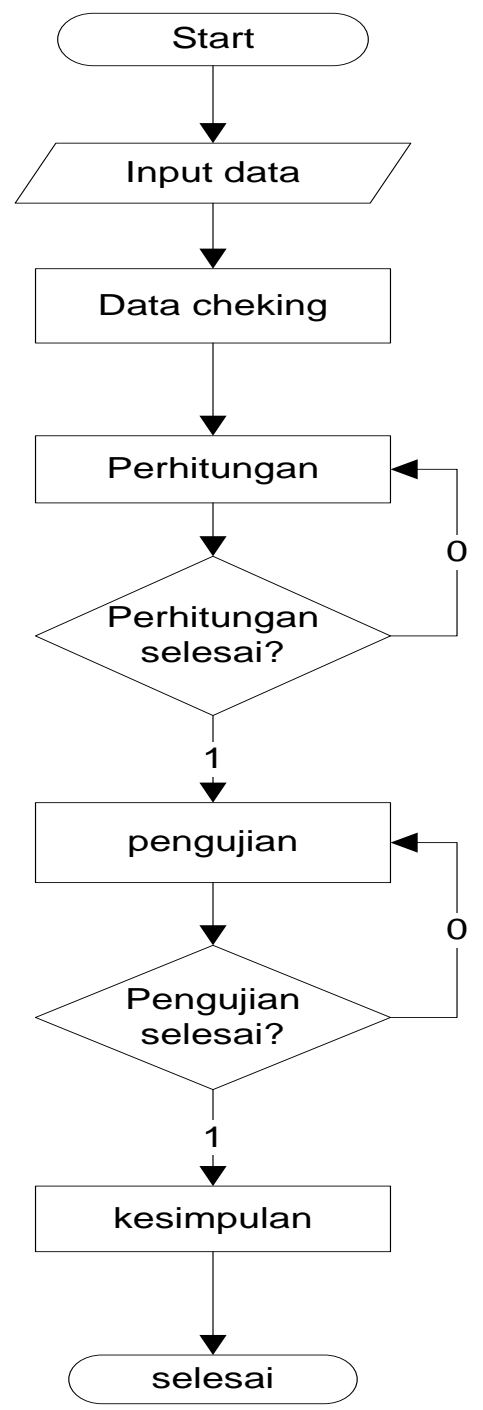

Gambar 1. Diagram Alir Jaringan Syaraf Tiruan Perceptron

Selanjutnya, untuk alur perhitungan atau penerapan algoritma Perceptron dapat dilihat pada flowchart berikut. 
Kapita, S.N., Mahdi, S., Tempola, F. 2020. Jaringan Syaraf Tiruan, algoritma perceptron, klasifikasi, akurasi, kurikulum

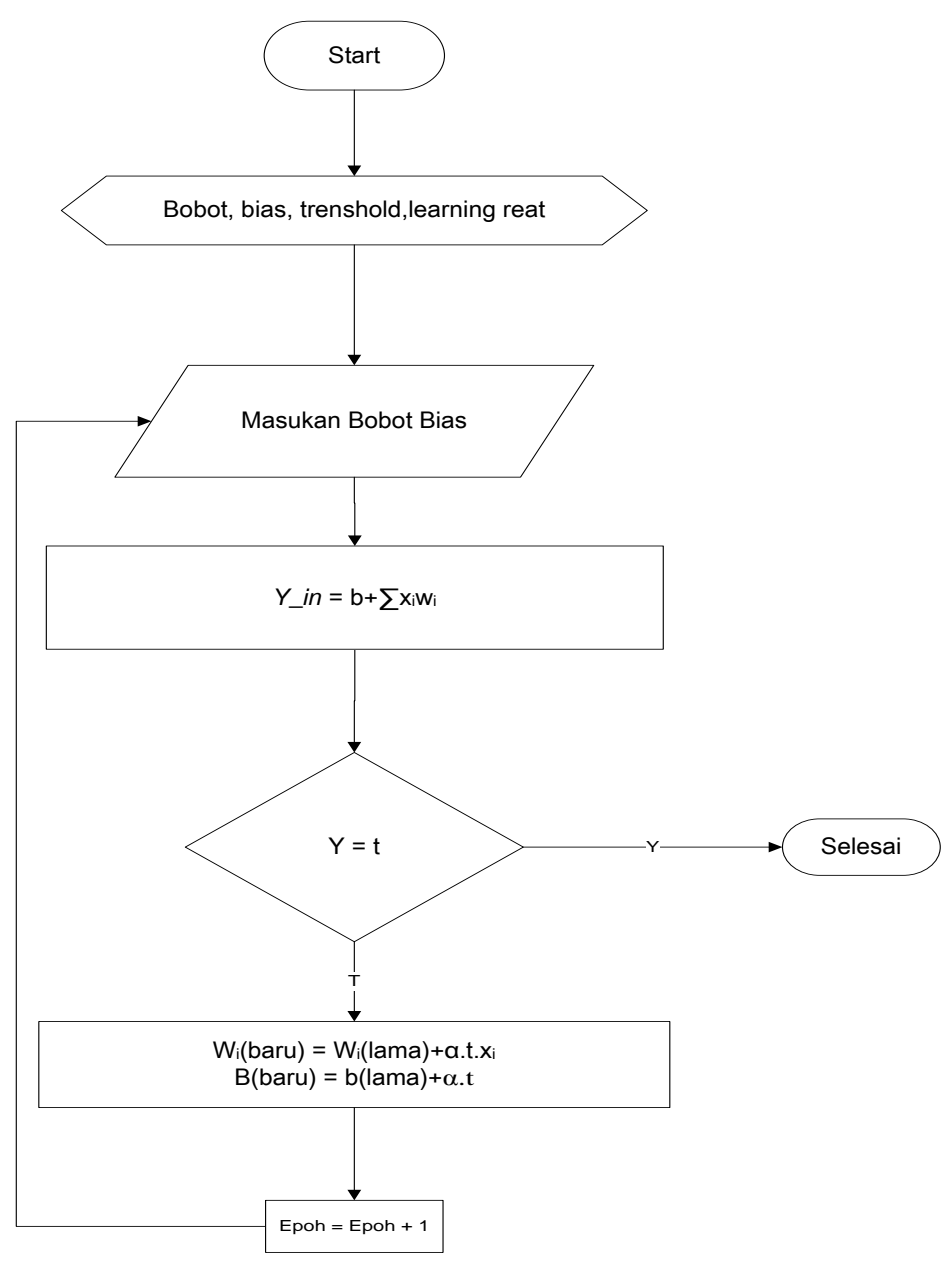

Gambar 2. Flowchart Algoritma Perceptron

Pada Gambar 2 di atas, terdapat beberapa tahapan diantaranya:

1. Inisialisasi bobot, bias, tresshold, dan learning reat.

2. Input bias dan bobot.

3. Menghitung responden untuk input-outputnya.

4. Membandingkan nilai output jaringan $Y$ dengan target $t$.

5. Jika $Y=t$, maka dinyatakan telah selesai, namun jika $Y \neq t$, maka dilakukan perhitungan bobot dan bias baru.

Jika telah didapatkan bobot baru, selanjutnya dilakukan perhitungan ke data berikutnya, hingga jaringan sesuai dengan target atau iterasi terpenuhi (Marcos \& Hidayah, 2014).

\section{HASIL DAN PEMBAHASAN}

\section{Dataset Pengetahuan}

Dataset pengetahuan merupakan data hasil belajar siswa pada ranah pengetahuan yang terekam dalam satu semester, yakni Hasil Penilaian Harian (HPH), Hasil Penilaian Tengah Semester (HPTS), dan Hasil Penilaian Akhir Semester (HPAS) dengan jumlah data yang diperoleh sebanyak 73 data. 
Tabel 1. Hasil normalisasi yang awalnya berupa nilai siswa dengan rentang nilai 0 100 dari kriteria atau parameter $\mathrm{X}_{1}, \mathrm{X}_{2}$ dan $\mathrm{X}_{3}$ kemudian menggunakan rumus normalisasi min-max normalization

\begin{tabular}{ccccc}
\hline Data ke & $\mathbf{X}_{\mathbf{1}}$ & $\mathbf{X}_{\mathbf{2}}$ & $\mathbf{X}_{\mathbf{3}}$ & $\mathbf{N R}$ \\
\hline $\mathbf{1}$ & 1 & 0.929 & 0.963 & 1 \\
$\mathbf{2}$ & 1 & 0.929 & 1 & 1 \\
$\mathbf{3}$ & 0.5 & 0.429 & 0.444 & 0 \\
$\mathbf{4}$ & 0.536 & 0.536 & 0.407 & 0 \\
$\mathbf{5}$ & 0.464 & 0.429 & 0.37 & -1 \\
$\mathbf{6}$ & 0.5 & 0.429 & 0.37 & 0 \\
$\mathbf{7}$ & 0.464 & 0.429 & 0.444 & -1 \\
$\mathbf{8}$ & 0.964 & 0.893 & 0.926 & 1 \\
$\mathbf{9}$ & 0.929 & 0.536 & 0.741 & 0 \\
$\mathbf{1 0}$ & 0.786 & 0.536 & 0.741 & 0 \\
$\mathbf{1 1}$ & 0.5 & 0.5 & 0.444 & 0 \\
$\mathbf{1 2}$ & 0.536 & 0.536 & 0.481 & 0 \\
$\mathbf{1 3}$ & 0.464 & 0.464 & 0.407 & -1 \\
$\mathbf{1 4}$ & 0.464 & 0.536 & 0.407 & 0 \\
$\mathbf{1 5}$ & 0.464 & 0.536 & 0.37 & 0 \\
$\mathbf{. .}$ &.. &.. &.. &.. \\
$\mathbf{. .}$ &.. &.. &.. &. \\
$\mathbf{7 3}$ & 0.179 & 0 & 0.185 & -1 \\
\hline
\end{tabular}

Keterangan:

1. $\mathrm{X}_{1} \quad$ : Parameter Inputan hasil penilaian harian

2. $\mathrm{X}_{2} \quad$ : Parameter inputan hasil penilaian tengah semester

3. $\mathrm{X}_{3} \quad$ : Parameter inputan hasil penilaian akhir semester

4. NR : data nilai predikat (A, B, dan C) yang diperoleh siswa dan ditransformasikan ke angka $(1,0$, dan - 1$)$

5. Min-Max Normalization: rumus normalisasi $x_{n}=\frac{x-x_{\min }}{x_{\max }-x_{\min }}$

\section{Analisis Metode}

Pada bagian ini akan dilakukan analisis metode Perceptron untuk mencari tingkat akurasi dalam mengklasifikasikan kategori data uji. Data uji yang akan digunakan pada analisis metode sebanyak 24 data yang telah dinormalisasi sebelumnya. Untuk lebih jelasnya data tersebut dapat dilihat pada Tabel 2.

Tabel 2. Data uji yang sudah dinormalisasi sebanyak 24 data

\begin{tabular}{cccccl}
\hline \multirow{2}{*}{ Data Ke } & \multicolumn{3}{c}{ PARAMETER } & \multirow{2}{*}{ NR } & Keterangan \\
\cline { 2 - 4 } & $\mathbf{X}_{\mathbf{1}}$ & $\mathbf{X}_{\mathbf{2}}$ & $\mathbf{X}_{\mathbf{3}}$ & & \\
\hline $\mathbf{5 0}$ & 0.607 & 0.643 & 0.556 & 1 & Sangat Baik \\
$\mathbf{5 1}$ & 0.714 & 0.821 & 0.815 & 1 & Sangat Baik \\
$\mathbf{5 2}$ & 0.643 & 0.821 & 0.815 & 1 & Sangat Baik \\
$\mathbf{5 3}$ & 0 & 0 & 0 & -1 & Cukup \\
$\mathbf{5 4}$ & 0.893 & 0.821 & 0.815 & 1 & Sangat Baik \\
$\mathbf{5 5}$ & 0.893 & 0.821 & 0.852 & 1 & Sangat Baik \\
$\mathbf{5 6}$ & 0.607 & 0.679 & 0.37 & 0 & Baik \\
$\mathbf{5 7}$ & 0.714 & 0.714 & 0.704 & 1 & Sangat Baik \\
$\mathbf{5 8}$ & 0.643 & 0.821 & 0.741 & 1 & Sangat Baik \\
$\mathbf{5 9}$ & 0.643 & 0.643 & 0.741 & 1 & Sangat Baik \\
$\mathbf{6 0}$ & 0.536 & 0.429 & 0.63 & 0 & Baik \\
$\mathbf{6 1}$ & 0.607 & 0.679 & 0.667 & 1 & Sangat Baik \\
$\mathbf{6 2}$ & 0.571 & 0.429 & 0.444 & 0 & Baik \\
$\mathbf{6 3}$ & 0.357 & 0.357 & 0.185 & 0 & Baik
\end{tabular}


Kapita, S.N., Mahdi, S., Tempola, F. 2020. Jaringan Syaraf Tiruan, algoritma perceptron, klasifikasi, akurasi, kurikulum

\begin{tabular}{lccccl}
$\mathbf{6 4}$ & 0.536 & 0.821 & 0.37 & 0 & Baik \\
$\mathbf{6 5}$ & 0.679 & 0.357 & 0.63 & 0 & Baik \\
$\mathbf{6 6}$ & 0.571 & 0.714 & 0.926 & 1 & Sangat Baik \\
$\mathbf{6 7}$ & 0.429 & 0.714 & 0.704 & 1 & Sangat Baik \\
$\mathbf{6 8}$ & 0.893 & 1 & 0.889 & 1 & Sangat Baik \\
$\mathbf{6 9}$ & 0.179 & 0.107 & 0.259 & 0 & Baik \\
$\mathbf{7 0}$ & 0.429 & 0.321 & 0.444 & 0 & Baik \\
$\mathbf{7 1}$ & 0.429 & 0.357 & 0.185 & 0 & Baik \\
$\mathbf{7 2}$ & 0.286 & 0.357 & 0.37 & 0 & Baik \\
$\mathbf{7 3}$ & 0.179 & 0 & 0.185 & -1 & Cukup \\
\hline
\end{tabular}

Setelah itu setiap data uji dihitung dengan bobot akhir yang sudah dilatih. Proses perhitungan dilakukan hanya pada tahapan fungsi aktivasi. Selanjutnya dilakukan pengecekan keluaran dengan kriteria:

$$
\begin{aligned}
& \mathrm{y}=1 \text { jika } y \_ \text {in }>0.5, \\
& \mathrm{y}=0 \text { jika }-0.5 \leq \mathrm{y} \_ \text {in } \leq 0.5, \\
& \mathrm{y}=-1 \text { jika y_in }<-0.5 .
\end{aligned}
$$

\begin{tabular}{|c|c|c|c|c|c|c|c|}
\hline \multirow[t]{2}{*}{ Nis } & \multicolumn{3}{|c|}{ PARAMETER } & \multirow[t]{2}{*}{ NR } & \multicolumn{3}{|c|}{ Hasil perhitungan } \\
\hline & $X_{1}$ & $\mathbf{X}_{2}$ & $\mathbf{X}_{3}$ & & Keterangan & Sistem Baca & Y-in \\
\hline 50 & 0.607 & 0.643 & 0.556 & 1 & Sangat Baik & Sangat Baik & 0.5602814 \\
\hline 51 & 0.714 & 0.821 & 0.815 & 1 & Sangat Baik & Sangat Baik & 1.0266356 \\
\hline 52 & 0.643 & 0.821 & 0.815 & 1 & Sangat Baik & Sangat Baik & 0.9413717 \\
\hline 53 & 0 & 0 & 0 & -1 & Cukup & Cukup & -1 \\
\hline 54 & 0.893 & 0.821 & 0.815 & 1 & Sangat Baik & Sangat Baik & 1.2415967 \\
\hline 55 & 0.893 & 0.821 & 0.852 & 1 & Sangat Baik & Sangat Baik & 1.2795254 \\
\hline 56 & 0.607 & 0.679 & 0.37 & 0 & Baik & Baik & 0.3842468 \\
\hline 57 & 0.714 & 0.714 & 0.704 & 1 & Sangat Baik & Sangat Baik & 0.869354 \\
\hline 58 & 0.643 & 0.821 & 0.741 & 1 & Sangat Baik & Sangat Baik & 0.8655143 \\
\hline 59 & 0.643 & 0.643 & 0.741 & 1 & Sangat Baik & Sangat Baik & 0.7931573 \\
\hline 60 & 0.536 & 0.429 & 0.63 & 0 & Baik & Baik & 0.4638839 \\
\hline 61 & 0.607 & 0.679 & 0.667 & 1 & Sangat Baik & Sangat Baik & 0.6887015 \\
\hline 62 & 0.571 & 0.429 & 0.444 & 0 & Baik & Baik & 0.3152468 \\
\hline 63 & 0.357 & 0.357 & 0.185 & 0 & Baik & Baik & -0.2365147 \\
\hline 64 & 0.536 & 0.821 & 0.37 & 0 & Baik & Baik & 0.3567059 \\
\hline 65 & 0.679 & 0.357 & 0.63 & 0 & Baik & SANGAT BAIK & 0.6063446 \\
\hline 66 & 0.571 & 0.714 & 0.926 & 1 & Sangat Baik & Sangat Baik & 0.9251975 \\
\hline 67 & 0.429 & 0.714 & 0.704 & 1 & Sangat Baik & Sangat Baik & 0.5270975 \\
\hline 68 & 0.893 & 1 & 0.889 & 1 & Sangat Baik & Sangat Baik & 1.3902176 \\
\hline 69 & 0.179 & 0.107 & 0.259 & 0 & Baik & Baik & -0.4760425 \\
\hline 70 & 0.429 & 0.321 & 0.444 & 0 & Baik & Baik & 0.100817 \\
\hline 71 & 0.429 & 0.357 & 0.185 & 0 & Baik & Baik & -0.1500499 \\
\hline 72 & 0.286 & 0.357 & 0.37 & 0 & Baik & Baik & -0.1321351 \\
\hline 73 & 0.179 & 0 & 0.185 & -1 & Cukup & Cukup & -0.5953954 \\
\hline
\end{tabular}

Hasil perhitungan pengujian dapat dilihat pada Tabel 3.

Tabel 3. Hasil pengujian data uji

Keterangan: Tulisan yang berwarna merah merupakan hasil klasifikasi yang salah atau tidak sesuai dengan data labelnya

Dari Tabel 3 di atas, selanjutnya dilakukan analisis tingkat akurasi. Untuk mencari keakuratan data dilakukan dengan menggunakan persamaan recognition rate. Tahap awal adalah menentukan jumlah data benar dan jumlah data sampel atau data uji seperti berikut:

Jumlah data benar $\quad=23$

Jumlah sampel $\quad=24$ 
$\begin{aligned} \text { Recognition Rate } & =\frac{\sum \text { correct }}{\sum \text { sample }} \times 100 \% \\ & =\frac{23}{24} \times 100 \%=96 \%\end{aligned}$

Keterangan:

Akurasi merupakan ketepatan sistem dalam mengklasifikasikan data. Data testing atau uji berjumlah 24 data, dengan pembagian data yaitu 1:23 atau data berkategori positive sebanyak 23, sedangkan data berkategori negative sebanyak 1 . Sistem berhasil mengklasifikasikan 23 data, dengan rincian 13 data positive (1); 9 data Positive (0); dan 2 data negative (-1), sehingga diperoleh persentase keakuratan sebesar $96 \%$.

\section{Analisis Hasil Pengujian}

Dari hasil pengujian sistem aplikasi dengan algoritma Perceptron sebanyak 13 kali pengujian, dimana 4 kali dengan bobot yang sama (id bobot 1$)$ dengan nilai $\left(\mathrm{W}_{1}=0.1, \mathrm{~W}_{2}=0.2, \mathrm{~W}_{3}=0.3\right.$, dan $b=0.5$ ) namun dengan laju pembelajaran yang berbeda dan akurasi tertinggi adalah $96 \% ; 4$ percobaan dengan bobot yang berbeda (id bobot 3 ) dengan nilai $\left(\mathrm{W}_{1}=0.3, \mathrm{~W}_{2}=0.4, \mathrm{~W}_{3}=0.5\right.$, dan $b=0.3$ ) namun dengan laju pembelajaran yang sama dan akurasi tertinggi adalah $88 \% ; 2$ percobaan dengan bobot yang berbeda (id bobot 2 ) dengan nilai $\left(\mathrm{W}_{1}=0.1, \mathrm{~W}_{2}=0.01, \mathrm{~W}_{3}=0.02\right.$, dan $b=0.003$ ) namun dengan pembelajaran yang sama dan memiliki akurasi tertinggi adalah 92\%; dan 3 percobaan dengan bobot dan laju pembelajaran yang sama namun dengan jumlah epoch yang berbeda dan memiliki hasil akurasi tertinggi yaitu $79 \%$.

Dari 13 kali pengujian diatas didapatkan akurasi yang baik adalah pada pengujian pertama dengan bobot awal yang id-nya 1 , dengan nilai dan pembelajaran 0,1 , dan maksimal iterasi 10.000 sehingga berhasil diperoleh presentase akurasi tertinggi yaitu 96\%.

\section{Grafik Analisis Hasil Pengujian}

Setelah dilakukan berbagai macam perubahan nilai pembelajaran maupun pemberian nilai bobot dan bias awal sehingga pengujian data uji memiliki hasil persentase akurasi yang berbeda-beda seperti pada Gambar 3 berikut.

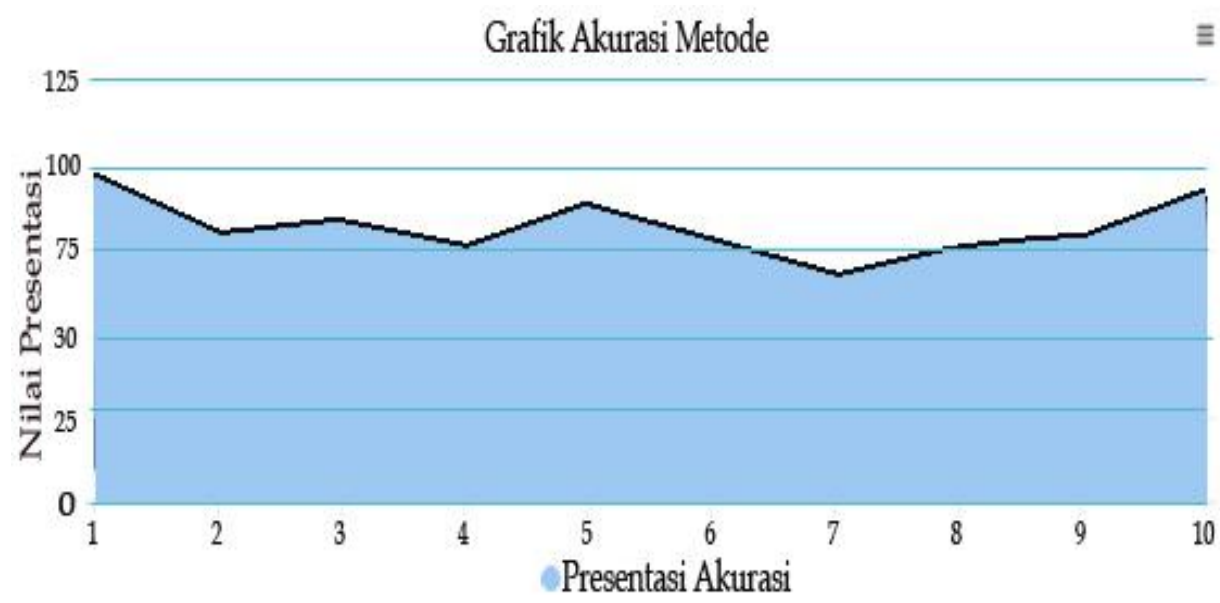

Gambar 3. Grafik Analisis Hasil Pengujian 


\section{Implementasi Interface}

\section{Halaman Latih Perceptron}

Halaman latih Perceptron menyajikan daftar model yang digunakan (metode Perceptron) dengan memuat tentang pemberian bobot dan bias awal, pemberian laju pembelajaran, serta batas iterasi (epoch).

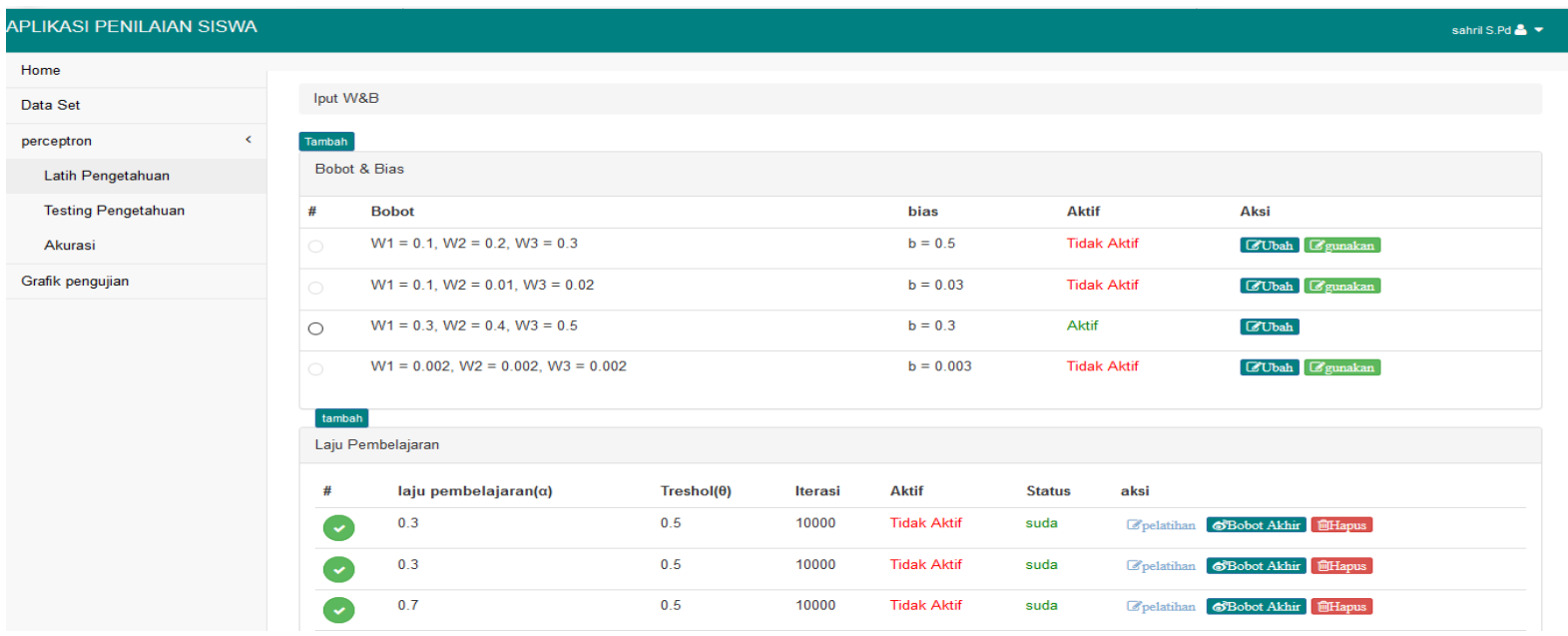

Gambar 4. Halaman Latih Perceptron

\section{KESIMPULAN}

Hasil penelitian menunjukkan bahwa Jaringan Syaraf Tiruan Perceptron berhasil diimplementasikan untuk klasifikasi penilaian siswa pada ranah pengetahuan. Hasil pengujian metode dengan jumlah data uji sebanyak 24 data, diperoleh tingkat akurasi tertinggi yaitu $96 \%$. Hasil akurasi ini dapat dipengaruhi oleh jumlah iterasi (epoch). Akurasi dikategorikan tinggi apabila jumlah epoch semakin banyak, namun akurasi rendah jika jumlah epoch sedikit. Selain itu, variansi pembelajaran dengan learning rate yang berbeda-beda juga dapat menentukan tingkat keakuratan. Akurasi akan meningkat (naik) apabila leraning rate semakin kecil atau mendekati 0, sebaliknya akurasi akan mengalami penurunan apabila lerning rate semakin tinggi atau mendekati 1 . Hasil pengujian sistem dengan menggunakan metode White-Box testing juga berhasil dilakukan, dengan menguji setiap path-path pada reaning treaning dan testing dalam metode perceptron.

Aplikasi penilaian siswa dengan menggunakan metode Jaringan Syaraf Tiruan Perceptron dapat dibuat dengan bahasa pemrograman PHP, paket XAMPP Control pada versi 3.2.3 Apache sebagai webserver, dan MySQL sebagai DBMS, Sublime Text 3 sebagai editor.

\section{SARAN}

Tampilan pada aplikasi ini masih sangat terbatas karena penelitian ini difokuskan pada penerapan metode. Diharapkan pada penelitian selanjutnya dapat dikembangkan dari segi desain interface sehingga lebih menarik dan mudah digunakan. 


\section{TECHNO: Vol. 09 (01) Mei 2020}

\section{DAFTAR PUSTAKA}

Ardian, Y., \& Abidin, Z. (2014). Sistem Pendukung Keputusan Penilaian Siswa Berprestasi Kurikulum 2013 Berbasis Web pada SMK Negeri 1 Gedangan Menggunakan Metode Saw. BIMASAKTI: Jurnal Riset Mahasiswa FTI UNIKAMA, 1(1), 1-7.

Arliyanto, G. S. (2016). Pengembangan Tes Minat dan Bakat dengan Jaringan Syaraf Tiruan (JST) Perceptron untuk Memprediksi Potensi Siswa Bidang Olahraga Sepak Bola.

http://eprints.dinus.ac.id/id/eprint/21863

Barakbah, A. R., Karlita, T., \& Ahsan, A. S. (2013). Logika dan Algoritma. In Surabaya: Politeknik Elektronika Negeri Surabaya.

Heryati, A., Erduandi, E., \& Terttiaavini, T. (2018). Penerapan Jaringan Saraf Tiruan Untuk Memprediksi Pencapaian Prestasi Mahasiswa. Konferensi Nasional Sistem Informasi (KNSI) 2018, 1158-1163.

Kapita, S. N. (2020). Aplikasi Jaringan Syaraf Tiruan Kohonen Self Organizing Map (K-SOM) pada Data Mutu Sekolah. JIKO (Jurnal Informatika Dan Komputer), 3(1), 56-61.

Kemendikbud. (2016). Panduan Penilaian Oleh Pendidik dan Satuan Pendidikan Untuk Sekolah Menengah Pertama. In Kementerian Pendidikan dan Kebudayaan Republik Indonesia. Kemendikbud RI.

Kokyay, S., Kilinc, E., Uysal, F., Kurt, H., Celik, E., \& Dugenci, M. (2020). A Prediction Model of Artificial Neural Networks in Development of Thermoelectric Materials with Innovative Approaches. In Engineering Science and Technology, an International Journal. Elsevier. https://doi.org/https://doi.org/10.1016/j.jestch.2020.04.007

Kosasi, S. (2014). Penerapan Metode Jaringan Saraf Tiruan Backpropagation untuk Memprediksi Nilai Ujian Sekolah. Jurnal Teknologi, 7(1), 20-28.

Lesnussa, Y. A., Latuconsina, S., \& Persulessy, E. R. (2015). Aplikasi Jaringan Saraf Tiruan Backpropagation untuk Memprediksi Prestasi Siswa SMA (Studi kasus: Prediksi Prestasi Siswa SMAN 4 Ambon). Jurnal Matematika Integratif, ISSN, 1412-6184.

Marcos, H., \& Hidayah, I. (2014). Implementasi Data Mining Untuk Klasifikasi Nasabah Kredit Bank 'X' Menggunakan Classification Rule. Semin. Nas. Teknol. Inf. Dan Multimed, 1-7.

Matondang, Z. A. (2013). Jaringan Syaraf Tiruan dengan Algoritma Backpropagation untuk Penentuan Kelulusan Sidang Skripsi. Pelita Informatika: Informasi Dan Informatika, 4(1).

Paramita, N. K. D. P. (2016). Peramalan Siwa-Siswi SMA yang diterima Pada Perguruan Tinggi Menggunakan Metode Jaringan Syaraf Tiruan Backpropagation (Studi Kasus Pada SMA Negeri 1 Genteng-Banyuwangi) [Institut Teknologi Sepuluh Nopember Surabaya]. http://repository.its.ac.id/id/eprint/72891

Prabowo, A. B. (2014). Sistem Pakar Untuk Mendiagnosa Penyakit Infeksi Saluran Pernafasan Akut (ISPA) Berbasis Web. J. Sarj. Tek. Inform, 2(1), 1-5.

Purnomo, D. (2017). Model Prototyping Pada Pengembangan Sistem Informasi. JIMP-Jurnal Informatika Merdeka Pasuruan, 2(2).

Sari, Y., Syah, I., \& Basri, M. (2015). Faktor Terhambatnya Penerapan Kurikulum 2013 Terhadap Guru Tingkat SMA di Bandar Lampung. PESAGI (Jurnal Pendidikan Dan Penelitian Sejarah), 3(2).

Wijaya, K. (2019). Implementasi Metode Prototype Dalam Rancang Bangun Sistem Informasi Perpustakaan Menggunakan Java (Netbeans 7.3)(Studi Kasus SMK N 01 Prabumulih). Jurnal Sisfokom (Sistem Informasi Dan Komputer), 8(1), 53-60. 